\title{
Investigation of Isatis Tinctoria and Isatis Buschiana Stalks as Raw Materials for Pulp and Paper Production
}

\section{Istraživanje mogućnosti upotrebe stabljika biljki Isatis tinctoria i Isatis buschiana kao sirovine za proizvodnju celuloze i papira}

\author{
Original scientific paper • Izvorni znanstveni rad \\ Received-prispjelo: 7. 12. 2015. \\ Accepted-prihvaćeno: 5. 5. 2016. \\ UDK: $630 * 861.069$ \\ doi:10.5552/drind.2016.1542
}

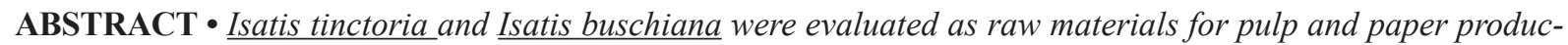

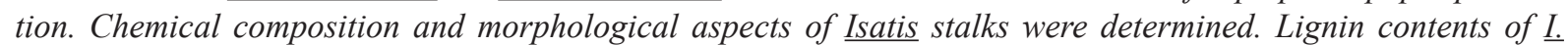
tinctoria and I. buschiana were $23.9 \%$ and $19.9 \%$, respectively. $\alpha$-cellulose ratio was found to be $48.5 \%$ in $\underline{I}$. tinctoria and $32.9 \%$ in I. buschiana. Fiber length, fiber diameter, lumen diameter and cell wall thickness were measured and the obtained data was used to calculate felting rate, elasticity coefficient, rigidity coefficient, runkel index and F factor. Handsheets were produced from Isatis stalks, and physical and optical properties were determined. Breaking length, tear index and burst index values were higher for the beaten pulp than for unbeaten pulp, while brightness and whiteness values were higher in unbeaten pulp.
\end{abstract}

Key words: I. tinctoria, I. buschiana, chemical composition, pulp, paper

SAŽETAK • U radu su istražene mogućnosti upotrebe stabljike biljaka Isatis tinctoria i Isatis buschiana kao sirovine za proizvodnju celuloze i papira. Određeni su kemijski sastav i morfološka svojstva stabljike. Sadržaj lignina u stabljici I. tinctoria bio je 23,9\%, a u stabljici I. buschiana 19,9\%. U stabljici I. tinctoria utvrđen je udjel $\alpha$-celuloze od $48,5 \%$, a u stabljici I. buschiana taj je postotak iznosio 32,9\%. Izmjereni su duljina i promjer vlakanaca, promjer pore i debljina stanične stijenke, a dobiveni su podaci iskorišteni za izračunavanje brzine filcanja, koeficijenta elastičnosti, koeficijenta krutosti, Runkelova indeksa i F-faktora. Od stabljika biljaka Isatis tinctoria i Isatis buschiana proizvedeni su listovi papira kojima su zatim određena fizikalna i optička svojstva. Utvrđeno je da je veće vrijednosti duljine lomljenja, indeksa cijepanja i indeksa pucanja imao papir od mljevene celuloze nego papir od nemljevene celuloze, dok je papir od nemljevene celuloze imao veće vrijednosti sjajnosti $i$ bjeline.

Ključne riječi: I. tinctoria, I. buschiana, kemijski sastav, celuloza, papir

\footnotetext{
${ }^{1}$ Authors are professors at Biology Department, Faculty of Science and Letters, KSU, Kahramanmaras, Turkey. ${ }^{2}$ Authors are professors at Forest Industry Engineering Department, Faculty of Forestry, KSU, Kahramanmaras, Turkey.

Autori su profesori Biološkog odsjeka, Fakultet prirodoslovnih znanosti, KSU, Kahramanmaras, Turska. ${ }^{2}$ Autori su profesori Odsjeka za industrijsku preradu drva, Šumarski fakultet, KSU, Kahramanmaras, Turska.
} 


\section{INTRODUCTION}

\section{UVOD}

The growth of paper consumption leads to the increase of the demand for fibrous material in pulp and paper industry (Daud and Law, 2010). Due to decreases in forests and increasing environmental awareness, seeking alternative non-wood raw metarials for papermaking has been the subject of scientific interest (Kaldor, 1992). Non-wood plant fibers, such as bagasse, wheat and rice straws, bamboo and kenaf are being used in the manufacture of pulp and paper (Ashori et al., 2006). Search for new non-wood raw materials will lead to discover alternatives to wood-based raw materials. Cotton (Gossypium hirsutum) stalks (Gencer et al., 2001; Tutus et al., 2010a), Crambe orientalis and C. tataria (Tutus et al., 2010b), and tea (Camellia sinensis) wastes (Tutus et al., 2015) were evaluated for their chemical composition and fiber characteristics.

I. tinctoria L. (Brassicaceae) or woad is a biennial or perennial herb growing up to $120 \mathrm{~cm}$ in height (Stoker et al., 1998a; Guarino et al., 2000). The flowers are small and yellow in color, and the leaves are hastate with minute auricles (Guarino et al., 2000). I. tictoria is one of the sources of the blue dye indigo (Maugard et al., 2001) and was cultivated in the Mediterranean countries for centuries to produce indigo (Fréchard et al., 2001; Stoker et al., 1998b). Besides dyeing properties, phytochemical, biological and pharmacological investigations have been carried out on I. tinctoria due to its medicinal properties. Antibacterial, antifungal, antiviral and cytoinhibitory activities were screened from Isatis extracts and constituents were selected (Hamburger et al., 2002). I. buschiana is also a biennial or perennial plant species, the flowering time is in May-July and the fruits can be observed in June-August (Davis, 1965). The herb can grow up to $98 \mathrm{~cm}$ in height (Comlekcioglu et al., 2014). In contrast to $I$. tinctoria, blue coloring dye could not be obtained from I. buschiana (Comlekcioglu et al., 2015).

The aim of this study was to determine the chemical and morphological properties of I. tinctoria and I. buschiana stalks. Kraft-AQ pulping method of Isatis stalks was also investigated to evaluate the potential use of Isatis in pulp production. To the best of our knowledge, this is the first report evaluating the I. tinctoria and I. buschiana as a raw material for paper production. Isatis stalks waste obtained from indigo production is a sustainable fiber source since the waste is not used for another purpose. This waste should be used in the paper industry in order to provide income for indigo producers.

\section{MATERIALS AND METHODS}

\section{MATERIJAL I METODE}

\subsection{The plant materials}

2.1. Biljni materijal

I. tinctoria was grown in Kahramanmaras/Turkey in 2013 using the seeds provided from the previous study (Comlekcioglu et al., 2014) and stalks were ob- tained from the breeded I. tinctoria after 7 months. $I$. buschiana was collected from native flora in 2013 and identified using Flora of Turkey and East Aegean Islands (Davis, 1965).

\subsection{Morphological properties of fibers}

\subsection{Morfološka svojstva vlakanaca}

The fiber lengths and widths, lumen diameters, and cell wall thicknesses, as the morphological properties of raw materials, were measured with a microscope. To measure the fiber morphologic properties of the specimens $(0.5 \mathrm{~mm}$ thick and $2 \mathrm{~cm}$ long, parallel to the fiber), the chloride method was performed (Wise and Karl, 1962). In this method, specimens were immersed into chloride solution until they were defibered. Fiber dimension variables were measured using Olympus BX51 microscope with 10X ocular lens provided with a measuring scale. Fiber width and lumen diameter were measured with a magnification of $40 \mathrm{X}$ object lens and the fiber length was measured with a magnification of 10X object lens. Mean values were calculated from the measurement of 100 fibers in each plant. The felting rate, elasticity coefficient, rigidity coefficient, runkel index and $\mathrm{F}$ factor were calculated by using the equations below (Tutus et al., 2010b):

Felting rate $=$ Fiber length $/$ Fiber diameter

Elasticity coefficient $(\%)=$ Lumen diameter $/$ Fiber diameter $\times 100$

Rigidity coefficient (\%) = Cell wall thickness / Fiber diameter $\times 100$

Runkel index $=$ Cell wall thickness $\times 2 /$ Lumen Diameter

F ratio $(\%)=$ Fiber length $/$ Cell wall thickness $\times 100$

\subsection{Chemical properties of Isatis stalks}

\subsection{Kemijska svojstva stabljika biljaka Isatis}

Isatis stalks were prepared according to TAPPI T $264 \mathrm{~cm}-07$ for chemical analysis. Isatis stalks were analyzed for moisture, lignin, $\alpha$-cellulose, ash, ethanol-toluen-acetone solubility, cold and hot water solubility and $1 \% \mathrm{NaOH}$ solubility in accordance with the applicable standards: TAPPI T 264 om-88, TAPPI T 222 om-88, TAPPI T 203 os-71, TAPPI T 211 om-85, ASTM D1107 - 96, TAPPI T 207 om-88, TAPPI T 207 om-88, respectively. Holocellulose and cellulose contents of Isatis stalks were determined according to Wise's chloride method (Wise and Karl, 1962) and Kurscher-Hoffer method (Browning, 1967), respectively. The raw material samples, $5 \mathrm{~g}$ of oven-dried weight, were placed into a $500 \mathrm{~mL}$ Erlenmeyer flask, to which $200 \mathrm{~mL}$ of deionized water (having a temperature of $90{ }^{\circ} \mathrm{C}$ ) was then added, followed by $10 \mathrm{~mL}$ of acetic acid and $2.5 \mathrm{~g}$ of $80 \%(\mathrm{w} / \mathrm{w}) \mathrm{NaClO}_{2}$. An optional $25 \mathrm{~mL}$ Erlenmeyer flask was inverted in the neck of the reaction flask. The flask was kept in a water bath at $90{ }^{\circ} \mathrm{C}$ for $60 \mathrm{~min}$, at which time $10 \mathrm{~mL}$ of acetic acid and $2.5 \mathrm{~g}$ of $80 \%(\mathrm{w} / \mathrm{w}) \mathrm{NaClO}_{2}$ were added with shaking. The $60 \mathrm{~min}$ cycle was repeated for up to 6 cycles. At the end, the flask was stoppered and cooled with cold water to stop the reaction. The reaction mixture was then filtered using a tared fritted disk glass 
thimble, washed with cold water and acetone, and dried at $105^{\circ} \mathrm{C}$ until the crucible weight was constant, and the holocellulose content was calculated. The cellulose was obtained by refluxing wood meal three times for $1 \mathrm{~h}$ with a 1:4 (v/v) mixture of nitric acid and ethanol. Three replicates were done for each experiment, and mean values were used.

\subsection{Pulping and handsheets}

2.4. Priprema celuloze i listova papira

Air dried Isatis stalks were cleaned and cut into pieces about 6-8 $\mathrm{cm}$ long. To determine the optimum pulping conditions, 4 cooking experiments were carried out on Isatis stalks, using kraft-anthraquinone (AQ) processes. Pulping conditions are given in Table 1. Pulping experiments were performed in 15-L electrically heated laboratory rotary digester. At the end of pulping, the pulp was washed, disintegrated in a pulp mixer and screened on a $0.15 \mathrm{~mm}$ slotted plate. The pulp yield was determined as dry matter obtained on the basis of oven dried stalks. Screened pulp was beaten in a Hollander type beater to $55^{\circ} \mathrm{SR}$ freeness. Ten

Table 1 Pulping conditions for I. tinctoria and I. buschiana stalks

Tablica 1. Uvjeti pripreme celuloze od stabljika biljaka $I$. tinctoria i I. buschiana

\begin{tabular}{|l|c|}
\hline $\begin{array}{l}\text { Pulping conditions } \\
\text { Uvjeti pripreme celuloze }\end{array}$ & \\
\hline Active alkali / aktivne lužine & $23 \%$ \\
\hline Sulfidity / sulfidi & $25 \%$ \\
\hline AQ charge / AQ udio & $0 \%, 0.1 \%$, \\
& $0.3 \%, 0.5 \%$ \\
\hline $\begin{array}{l}\text { Cooking temperature / temperatura } \\
\text { kuhanja }\end{array}$ & $155^{\circ} \mathrm{C}$ \\
\hline Cooking time / vrijeme kuhanja & $90 \mathrm{~min}$ \\
\hline Penetration / prodiranje & $30 \mathrm{~min}$ \\
\hline $\begin{array}{l}\text { Liquor to stalk ratio / omjer otapala } i \\
\text { stabljika }\end{array}$ & $5 / 1(\mathrm{~L} / \mathrm{kg})$ \\
\hline
\end{tabular}

handsheets, with a grammage of $70 \pm 3 \mathrm{~g} / \mathrm{m}^{2}$, were made by using Rapid Kothen RK-21 paper sheet former according to TAPPI T 272 om-92.

\subsection{Determination of physical and optical properties}

2.5. Određivanje fizikalnih i optičkih svojstava

The breaking length, burst index, tear index, brightness, whiteness, opacity and yellowness were determined according to TAPPI T 494 om-88, TAPPI T 403 om-91, TAPPI T 414 om-88, ISO/DIS 2470, ISO/DIS 11475, ISO/DIS 2471 and ASTM E 313, respectively.

\section{RESULTS AND DISCUSSION 3. REZULTATI I RASPRAVA}

\subsection{Chemical composition}

3.1. Kemijski sastav

Table 2 shows the chemical properties and some solubility values of Isatis stalks and its comparison with several fibrous raw materials. Lignin contents of the studied Isatis stalks are comparable to hardwood and annual plants (20-24\%), and lower than softwoods (25-32\%). The holocellulose content of Isatis stalks were found as 67.1 and $70.1 \%$; most annual and coniferous plants were found between 61-82\%. $\alpha$-cellulose content of I. tinctoria $(48.5 \%)$ and I. buschiana (32.9\%) were found to be comparable to other nonwoods (Table 2). I. tinctoria and I. buschiana had higher ethanol-toluen-acetone, alkali and water solubility. The higher solubility resulted in lower pulp yield and higher BOD load in the effluent (Jahan et al., 2006).

\subsection{Morphological characteristics \\ 3.2. Morfološka svojstva}

Morphological characteristics of I. tinctoria and I. buschiana stalk fibers and the comparison of several raw material fibers are given in Table 3. The image of the fibers is shown in Figure 1. The mean fiber length

Table 2 Chemical composition of I. tinctoria and I. buschiana stalks and other raw materials

Tablica 2. Kemijski sastav stabljike biljaka I. tinctoria i I. buschiana te drugih sirovina

\begin{tabular}{|c|c|c|c|c|c|c|c|c|c|}
\hline $\begin{array}{c}\text { Raw material } \\
\text { Sirovina }\end{array}$ & 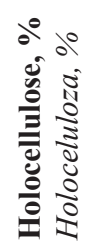 & 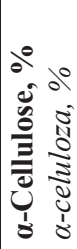 & 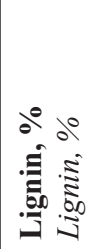 & 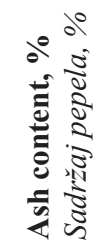 & 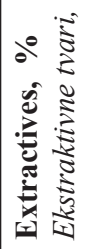 & 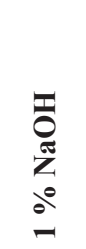 & 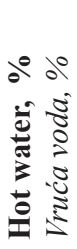 & 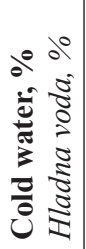 & $\begin{array}{c}\text { References } \\
\text { Literatura }\end{array}$ \\
\hline I. tinctoria & 67.1 & 48.5 & 23.9 & 4.9 & 4.4 & 43.8 & 17.2 & 13.6 & This study \\
\hline I. buschiana & 70.1 & 32.9 & 19.9 & 11.1 & 4.1 & 37.1 & 20.6 & 29.3 & This study \\
\hline A. membranaceus & 76.7 & 49.8 & 23.6 & 5.5 & - & 29.4 & 8.5 & 7.2 & Tutus et al., 2014 \\
\hline Poppy stalks / stabljike maka & 79,8 & 51.7 & 19.2 & 4.7 & - & 30.4 & 10.4 & 5.1 & Tutus et al., 2011 \\
\hline Cotton stalks / stabljike pamuka & 75.6 & 39.8 & 18.2 & 2.5 & 6.1 & 30.9 & 14.3 & 11.7 & Tutus et al., 2010a \\
\hline Wheat stalks / stabljike pšenice & 77.1 & 39.6 & 18.3 & 7.1 & 5.5 & 40.9 & 12.3 & 7.7 & Tutus and Eroglu, 2003 \\
\hline Corn stalks / stabljike kukuruza & 64.8 & 35.6 & 17.4 & 7.5 & 9.5 & 47.1 & 14.8 & - & Eroglu et al.,1992 \\
\hline Tea wastes / stpad od čaja & 60.8 & 26.5 & 36.9 & 4.5 & 15.2 & 54.1 & 31.4 & 10.9 & Tutus et al., 2015 \\
\hline Bamboo / bambus & 70.5 & 43.3 & 24.5 & 1.4 & 3.9 & 25.1 & 6.5 & - & Deniz and Ates, 2002 \\
\hline Softwood / meko drvo & $63-74$ & - & $25-32$ & $0.2-0.5$ & $1-5.8$ & $8-10$ & $1-5$ & $0.5-4$ & Kirci, 2006 \\
\hline Hardwood / tvrdo drvo & $72-82$ & - & $18-26$ & $0.2-0.7$ & $1-6.2$ & $12-25$ & $1-8$ & $0.2-4$ & Kirci, 2006 \\
\hline
\end{tabular}



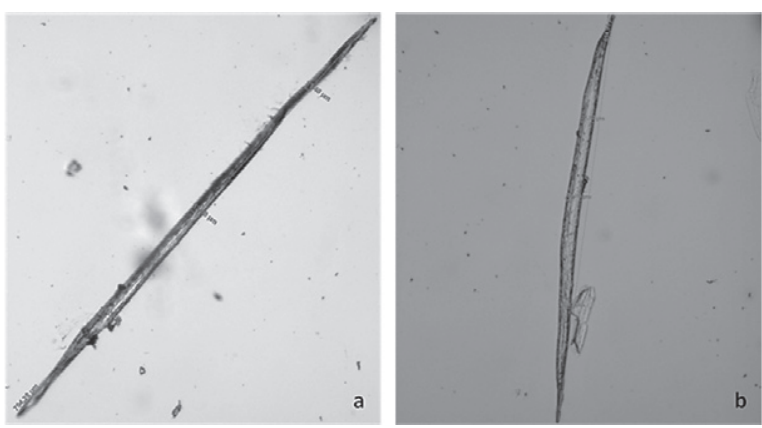

Figure 1 Fibers of macerated samples from I. tinctoria (a) and I. buschiana (b) stalks

Slika 1. Vlakanca macerata stabljike (a) I. tinctoria i (b) I. buschiana

of I. tinctoria and I. buschiana stalks was less than that of both softwood (2.7-4.6 $\mathrm{mm})$ and hardwood (0.7-1.6 $\mathrm{mm})$ fibers. The fiber width of Isatis stalks was less than that of hardwood fibers $(20.0-40.0 \mu \mathrm{m})$, however comparable to wheat and cotton stalks, golpata fronds and $C$. cardunculus (Table 3 ). The lumen width of $I s a$ tis stalks was found to be higher than that of wheat straw, and less than that of $C$. cardunculus. The fiber parameters calculated with the fiber characteristics are given in Table 4. Felting power is widely used to determine the suitability of raw material for paper production (Tutus et al., 2015). The felting power of I. tinctoria and I. buschiana were 39.7 and 38.1, respectively, and these values were close to the hardwoods. Although the Isatis stalks would be classified as short fibers, overall morphological properties of I. tinctoria and I. buschiana stalk fibers were found satisfactory for papermaking trials.
Table 5 shows the relationships between paper physical properties and fiber morphological properties. Increases of fiber length and decreases of cell wall thickness have a significant effect on paper physical properties. Burst, tear and double fold strength increase with the increase of fiber length. With the increase of cell wall thickness, burst and double fold strength decrease, while tear strength increases (Dinwoodie, 1965).

\subsection{Pulp yield \\ 3.3. Prinos celuloze}

Due to similar chemical composition and morphological characteristics of I. tinctoria and I. buschiana, the pulp and paper studies were performed by mixing the stalks of both Isatis species. In this study, the first pulping trials of Isatis stalks were performed using sodaAQ; however, pulp yield was found to be low. The values of delignification rate and screened yield were low; however, the screen reject value was high for the pulp obtained using soda-AQ (data not shown). Therefore, Isatis stalks were cooked by kraft-AQ at $23 \%$ active alkali and $25 \%$ sulfidity. As shown in Table 6, the increase of the AQ charge to $0.5 \%$ also increased the total pulp yield to $34.93 \%$. Anthraquinone (AQ) is used as a digester additive in the production of pulp by alkaline processes, as well as by the Kraft, the alkaline sulfite or the Soda-AQ processes. The anthraquinone is a redox catalyst. The reaction mechanism may involve single electron transfer. AQ oxidizes the reducing end of polysaccharides in the pulp, i.e., cellulose and hemicellulose, and thereby protects it from alkaline degradation (peeling) (Samp, 2008). The conditions were selected just to evaluate the pulping potentials of Isatis stalks as raw material. It is, therefore, necessary to optimize the con-

Table 3 Fiber characteristics of I. tinctoria and I. buschiana stalks and other raw materials Tablica 3. Svojstva vlakanaca stabljike I. tinctoria i I. buschiana te nekih drugih sirovina

\begin{tabular}{|l|c|c|c|c|c|c|}
\hline & $\begin{array}{c}\text { Wheat straw } \\
\text { Slama pšenice }\end{array}$ & $\begin{array}{c}\text { Cotton stalks } \\
\text { Stabljike pamuka }\end{array}$ & $\begin{array}{c}\text { Golpata fronds } \\
\text { Listovi golpate }\end{array}$ & $\begin{array}{c}\text { Cynara } \\
\text { cardunculus }\end{array}$ & I.tinctoria & I. buschiana \\
\hline $\begin{array}{l}\text { Fiber length, } \mathrm{mm} \\
\text { Duljina vlakanaca, } \mathrm{mm}\end{array}$ & 0.7 & 2.1 & 1.7 & 1.3 & 0.6 & 0.6 \\
\hline $\begin{array}{l}\text { Fiber width, } \mu \mathrm{m} \\
\text { Sirina vlakanaca, } \mu \mathrm{m}\end{array}$ & 13.2 & 9.7 & 10.0 & 18.8 & 15.7 & 15.9 \\
\hline $\begin{array}{l}\text { Lumen width, } \mu \mathrm{m} \\
\text { Sirina pora, } \mu \mathrm{m}\end{array}$ & 4.0 & - & - & 9.1 & 8.8 & 7.5 \\
\hline $\begin{array}{l}\text { Wall thickness, } \mu \mathrm{m} \\
\text { Debljina stijenki, } \mu \mathrm{m}\end{array}$ & 4.6 & - & - & 4.8 & 8.6 & 8.7 \\
\hline $\begin{array}{l}\text { Reference } \\
\text { Literatura }\end{array}$ & $\begin{array}{c}\text { Deniz } \text { et al., } \\
2004\end{array}$ & $\begin{array}{c}\text { Reddy and Yang, } \\
2009\end{array}$ & $\begin{array}{c}\text { Jahan } \text { et al., } \\
2006\end{array}$ & $\begin{array}{c}\text { Gominho } \text { et } \\
\text { al., } 2001\end{array}$ & This study & This study \\
\hline
\end{tabular}

Table 4 Comparison of fiber parameters of I. tinctoria and I. buschiana stalks with hardwoods and softwoods (Alkan et al., 2003; Istek et al., 2009; Tutus et al., 2014)

Tablica 4. Usporedba parametara vlakanaca stabljike I. tinctoria i I. buschiana s vlakancima tvrdoga i mekog drva (Alkan i sur., 2003.; Istek et al., 2009.; Tutus et al., 2014.)

\begin{tabular}{|l|c|c|c|c|c|}
\hline & $\begin{array}{c}\text { Felting rate } \\
\text { Brzina filcanja }\end{array}$ & $\begin{array}{c}\text { Elasticity coefficient } \\
\text { Koeficijent elastičnosti }\end{array}$ & $\begin{array}{c}\text { Rigidity coefficient } \\
\text { Koeficijent krutosti }\end{array}$ & $\begin{array}{c}\text { Runkel index } \\
\text { Runkelov indeks }\end{array}$ & $\begin{array}{c}\boldsymbol{F} \text { factor } \\
\text { F-faktor }\end{array}$ \\
\hline I. tinctoria & 39.7 & 47.2 & 26.4 & 1.1 & 150.1 \\
\hline I. buschiana & 38.1 & 47.5 & 26.8 & 1.2 & 142.2 \\
\hline $\begin{array}{l}\text { Softwoods } \\
\text { Meko drvo }\end{array}$ & $60-80$ & $55-75$ & $13-20$ & $0.3-0.8$ & $400-580$ \\
\hline $\begin{array}{l}\text { Hardwoods } \\
\text { Tvrdo drvo }\end{array}$ & $40-55$ & $35-55$ & $15-35$ & $0.5-1.8$ & $150-300$ \\
\hline
\end{tabular}


Table 5 The relationship between paper physical properties and fiber morphological properties (Bostanci, 1987; Bektas et al., 1999; Istek et al., 2009)

Tablica 5. Odnos fizikalnih svojstava papira i morfoloških svojstava vlakanaca (Bostanci, 1987.; Bektas et al., 1999.; Istek et al., 2009.)

\begin{tabular}{|l|c|c|c|c|}
\hline \multicolumn{1}{|c|}{$\begin{array}{c}\text { Relationships } \\
\text { Odnosi }\end{array}$} & $\begin{array}{c}\text { Burst strength } \\
\text { Čvrstoća pucanja }\end{array}$ & $\begin{array}{c}\text { Tear strength } \\
\text { Čvrstoća } \\
\text { cijepanja }\end{array}$ & $\begin{array}{c}\text { Double fold strength } \\
\text { Ćvrstoća dvostruko } \\
\text { savijenog papira }\end{array}$ & $\begin{array}{c}\text { Paper density(*) } \\
\text { Gustoća papira (*) }\end{array}$ \\
\hline $\begin{array}{l}\text { Fiber length increases } \\
\text { Duljina vlakanaca se povećava }\end{array}$ & + & ++ & + & - \\
\hline $\begin{array}{l}\text { Cell wall thickness increases } \\
\text { Debljina stijenke se povécava }\end{array}$ & - & + & -- & - \\
\hline $\begin{array}{l}\text { Cell wall thickness decreases } \\
\text { Debljina stijenke se smanjuje }\end{array}$ & + & - & ++ & ++ \\
\hline $\begin{array}{l}\text { Fiber length / fiber width increases } \\
\text { Duljina /sirina vlakanaca se povećava }\end{array}$ & - & & + & \\
\hline $\begin{array}{l}\text { Fiber curl increases } \\
\text { Uvijenost vlakanaca se povećava }\end{array}$ & - & + & + & - \\
\hline
\end{tabular}

(*): Porosity, air permeability, water holding capacity and bulkiness are inversely proportional to density./ Poroznost, propusnost zraka, sposobnost zadržavanja vode i voluminoznost obrnuto su proporcionalni gustoći.

(+) Positive effect / pozitivan utjecaj. (++) Certainly positive effects. / Sigurno pozitivan utjecaj.

(-) Negative effect. / Negativan utjecaj. (--) Certainly negative effects. / Sigurno negativan utjecaj.

ditions in further investigations. As a comparison, the pulp yield of golpata fronds (Jahan et al., 2006), C. cardunculus (Gominho et al., 2001), cotton stalks (Akgul and Tozluoglu, 2009) were $36.2 \%, 47 \%, 37.98 \%$, kiwi pulp screened yield $44.39 \%$ (Gencer, 2015) and Sorghum pulp screened yield $44.87 \%$ (Gencer and Sahin, 2015), respectively.

\subsection{Physical and optical properties}

3.4. Fizikalna i optička svojstva papira

Handsheets were produced from Isatis stalk pulp to determine their physical and optical properties. The measured physical and optical properties are given in Table 7. According to the results, higher values of the breaking length, tear index and burst index were recor- ded for the beaten pulp than for the unbeaten pulp, while brightness and whiteness were higher in unbeaten pulp. In this study, AQ charge further increased the breaking length and burst index, while it decreased the tear index. In beaten pulp, $0.1 \%$ AQ charge improved the brightness and whiteness by $6.3 \%$ and $10.02 \%$, respectively, and decreased the yellowness by $2.3 \%$. The physical properties of a pulp sheet are closely related to morphological properties of pulp fiber (Young, 1981). The breaking length, tear index and burst index of cotton stalks (Jimenez et al., 2007) were $4.4 \mathrm{~km}$, $0.26 \mathrm{mN} \cdot \mathrm{m}^{2} / \mathrm{g}$ and $2.13 \mathrm{kPa} \cdot \mathrm{m}^{2} / \mathrm{g}$, respectively. The breaking length, tear index and burst index of Paulownia elongata paper sheets were $1.66 \mathrm{~km}, 2.1 \mathrm{mN} \cdot \mathrm{m}^{2} / \mathrm{g}$ and $1.15 \mathrm{kPa} \cdot \mathrm{m}^{2} / \mathrm{g}$ (Ates et al., 2008), respectively.

Table 6 Cooking conditions and pulp yield of Isatis pulp

Tablica 6. Uvjeti kuhanja i prinos celuloze od stabljika I. tinctoria i I. buschiana

\begin{tabular}{|c|c|c|c|c|}
\hline $\begin{array}{c}\text { Cooking No } \\
\text { Kuhanje broj }\end{array}$ & $\begin{array}{c}\text { AQ charge, \% } \\
\text { AQ udio, \% }\end{array}$ & $\begin{array}{c}\text { Screened yield, \% } \\
\text { Prinos prosijavanja, \% }\end{array}$ & $\begin{array}{c}\text { Screen reject, \% } \\
\text { Skart prosijavanja, \% }\end{array}$ & $\begin{array}{c}\text { Total yield, \% } \\
\text { Ukupni prinos, \% }\end{array}$ \\
\hline 1 & 0 & 23.9 & 0.67 & 24.57 \\
\hline 2 & 0.1 & 25.37 & 0.72 & 26.09 \\
\hline 3 & 0.3 & 27.77 & 0.77 & 28.54 \\
\hline 4 & 0.5 & 31.09 & 3.84 & 34.93 \\
\hline
\end{tabular}

Table 7 Physical and optical properties of hand sheets made from beaten and unbeaten pulp

Tablica 7. Fizikalna i optička svojstva ručno izrađenih listova papira od mljevene i nemljevene celuloze

\begin{tabular}{|c|c|c|c|c|c|c|c|}
\hline $\begin{array}{l}\text { Cooking no } \\
\text { Kuhanje broj }\end{array}$ & $\begin{array}{c}\text { Breaking } \\
\text { length } \\
\text { Duljina } \\
\text { lomljenja } \mathrm{km} \\
\end{array}$ & $\begin{array}{l}\text { Tear index } \\
\text { Indeks } \\
\text { cijepanja } \\
\mathrm{mN} \cdot \mathrm{m}^{2} / \mathrm{g} \\
\end{array}$ & $\begin{array}{c}\text { Burst index } \\
\text { Indeks } \\
\text { pucanja } \\
\mathrm{kPa} \cdot \mathrm{m}^{2} / \mathrm{g} \\
\end{array}$ & $\begin{array}{c}\text { ISO } \\
\text { Brightness } \\
\text { ISO sjajnost, } \\
\% \\
\end{array}$ & $\begin{array}{c}\text { ISO } \\
\text { Whiteness } \\
\text { ISO bjelina } \\
\% \\
\end{array}$ & $\begin{array}{c}\text { ISO Opacity } \\
\text { ISO nepro- } \\
\text { zirnost } \\
\% \\
\end{array}$ & $\begin{array}{c}\text { ISO } \\
\text { Yellowness } \\
I S O \text { žutilo \% }\end{array}$ \\
\hline \multicolumn{8}{|c|}{ Unbeaten pulp / Nemljevena celuloza } \\
\hline 1 & 1.118 & 1.12 & 0.62 & 26.03 & 33.92 & 98.81 & 33.49 \\
\hline 2 & 1.849 & 0.88 & 0.96 & 26.67 & 34.22 & 99.33 & 32.6 \\
\hline 3 & 1.962 & 0.82 & 1.01 & 26.73 & 34.45 & 99.88 & 33.18 \\
\hline 4 & 2.059 & 0.85 & 0.92 & 26.63 & 34.28 & 99.88 & 34.03 \\
\hline \multicolumn{8}{|c|}{ Beaten pulp / Mljevena celuloza } \\
\hline 1 & 3.091 & 1.14 & 1.98 & 23.64 & 30.35 & 99.77 & 33.2 \\
\hline 2 & 3.330 & 1.03 & 2.17 & 25.22 & 33.73 & 99.65 & 32.44 \\
\hline 3 & 3.984 & 1.06 & 2.56 & 24.46 & 31.54 & 99.78 & 33.34 \\
\hline 4 & 3.808 & 0.90 & 2.62 & 23.58 & 30.71 & 98.65 & 34.71 \\
\hline
\end{tabular}


These values were comparable with the properties of Isatis paper sheet strength.

\section{CONCLUSIONS}

\section{ZAKLJUČAK}

Using non-wood raw materials has become a critical issue in regions with inadequate forest or wood resources. Therefore, evaluating the potential agricultural fiber sources as raw material for pulp and paper industry has received considerable attention. I. tinctoria is a well known plant as an indigo dye plant. I. tinctoria is an annual plant that grows in 7-8 months after the sowing. To the best of our knowledge, I. tinctoria and I. buschiana were evaluated as raw material for making pulp and paper for the first time in this study. As a conclusion, holocellulose, $\alpha$-cellulose and lignin in Isatis stalks were comparable to hardwood and several non-wood plants. It was found that physical strength was higher in beaten pulp, while optical properties were higher in unbeaten pulp. Although higher solubilities and lower felting coefficient will cause lower pulp yield and strength properties, Isatis stalks can be used for paper production when mixed with long fibrous materials. Besides, Isatis stalks can be used instead of wheat stalks in pulp and paper production as they have similar chemical and morphological properties. When considering the shortage of raw material in pulp and paper industry, the use of Isatis stalks with softwood pulp would contribute significantly to an economic supply of raw material for pulp and paper production.

\section{Acknowledgement - Zahvala}

We gratefully thank the Scientific and Technological Research Council of Turkey TUBITAK (Grant: 2209-A/2012) for funding this study.

\section{REFERENCES}

\section{LITERATURA}

1. Akgul, M.; Tozluoglu, A., 2009: A comparison of soda and soda-AQ pulps from cotton stalks. African Journal of Biotechnology, 8 (22): 6127-6133.

http://dx.doi.org/10.5897/AJB09.301

2. Ashori, A.; Harun, J.; Raverty, W. D.; Yusoff, M. N. M., 2006: Chemical and morphological characteristics of Malaysian cultivated kenaf (Hibiscus cannabinus) fiber. Polymer-Plastics Technology and Engineering, 45 (1): 131-134. http://dx.doi.org/10.1080/03602550500373782

3. Ates, S.; Ni, Y.; Akgul, M.; Tozluoglu, A., 2008: Characterization and evaluation of Paulownia elongota as a raw material for paper production. African Journal of Biotechnology, 7 (22): 4153-4158.

4. Bektas, I.; Tutus, A.; Eroglu, H., 1999: A Study of The Suitability of Calabrian Pine (Pinus brutia Ten.) for Pulp and Paper Manufacture. Turkish Journal of Agriculture and Forestry, 23 (3): 589-597.

5. Bostanci, S., 1987: Pulp Production and Bleaching Technology, Blacksea Technical University, Publication No: 114, Trabzon/ Turkey.

6. Browning, B. L., 1967: Methods of Wood Chemistry, vol. 2. Interscience/Wiley, New York.

7. Comlekcioglu, N.; Efe, L.; Karaman, S., 2014: Effects of different sowing times on the yield and agronomic chara- cters of Isatis tinctoria and Isatis buschiana in Kahramanmaras conditions. Journal of Tekirdag Agricultural Faculty, 11 (1): 67-78.

8. Comlekcioglu, N.; Efe, L.; Karaman, S., 2015: Extraction of Indigo from Some Isatis species and Dyeing Standardization Using Low-technology Methods. Brazilian Archives of Biology and Technology, 58 (1): 96-102. http://dx.doi.org/10.1590/S1516-8913201502658

9. Daud, W. R. W.; Law, K. N., 2010: Oil palm fibers as papermaking material: Potentials and challenges. BioResources, 6 (1): 901-917.

10. Davis, P. H., 1965: Flora of Turkey and the east Aegean Islands, vol I. Edinburg at the University Press, Edinburg, pp. 287-366.

11. Deniz, I.; Ates, S., 2002: Determination of optimum kraft pulping conditions using bamboo (Pyllotachys bambusoides), 2nd. National Black Sea Forestry Congress Proceedings, Artvin, Turkey, pp. 1072- 1084.

12. Deniz, I.; Kirci, H.; Ates, S., 2004: Optimization of wheat straw (Triticum durum) kraft pulping. Industrial Crops and Products, 19 (3): 237-243. http://dx.doi.org/10.1016/j. indcrop.2003.10.011

13. Dinwoodie, J. M., 1965: The relationship between fiber morphology and paper properties: a review of literature. Tappi, 48: 440-451.

14. Eroğlu, H.; Usta, M.; Kırc1, H., 1992: A Review of Oxygen Pulping Conditions of Some Non-Wood Plant Growing in Turkey. Tappi Pulping Conference, 215-22.

15. Fréchard, A.; Fabre, N.; Péan, C.; Montaut, S.; Fauvel, M. T.; Rollin, P.; Fourasté, I., 2001: Novel indole-type glucosinolates from woad (Isatis tinctoria L.). Tetrahedron Letters, 42 (51): 9015-9017.

http://dx.doi.org/10.1016/S0040-4039(01)02015-9

16. Gencer, A.; Eroğlu, H.; Özen, R., 2001: Medium density fiberboard manufacturing from cotton stalks. Inpaper International, 5 (2): 26-28.

17. Gencer, A., 2015: The utilization of kiwi (Actinidia deliciosa) pruning waste for kraft paper production and the effect of the bark on paper properties. Drewno, 58 (194): 103-113. DOI: 10.12841/wood.1644-3985.084.08.

18. Gencer, A.; Şahin, M., 2015: Identifying the conditions required for the $\mathrm{NaOH}$ method for producing pulp and paper from sorghum grown in Turkey. BioResources, 10 (2): $2850-2858$ http://dx.doi.org/10.15376/biores.10.2.2850-2858

19. Gominho, J.; Fernandez, J.; Pereira, H., 2001: Cynara cardunculus L. - a new fibre crop for pulp and paper production. Industrial Crops and Products, 13 (1): 1-10. http://dx.doi.org/10.1016/S0926-6690(00)00044-3

20. Guarino, C.; Casoria, P.; Menale, B., 2000: Cultivation and use of Isatis tinctoria L.(Brassicaceae) in Southern Italy. Economic Botany, 54 (3): 395-400. http://dx.doi.org/10.1007/BF02864789

21. Hamburger, M., 2002: Isatis tinctoria-from the rediscovery of an ancient medicinal plant towards a novel antiinflammatory phytopharmaceutical. Phytochemistry Reviews, 1 (3): 333-344. http://dx.doi.org/10.1023/A:1026095608691

22. Istek, A.; Tutus, A.; Gulsoy, K. G., 2009: The Effect of Tree Age on Fiber Morphology of Pinus pinaster and Paper Properties, KSU Journal of Engineering Sciences, 12 (1): $1-5$

23. Jahan, M. S.; Chowdhury, D. N.; Islam, M. K., 2006: Characterization and evaluation of golpata fronds as pulping raw materials. Bioresource technology, 97 (3): 401 406. http://dx.doi.org/10.1016/j.biortech.2005.04.003

24. Jiménez, L.; Pérez, A.; de la Torre, M. J.; Moral, A.; Serrano, L., 2007: Characterization of vine shoots, cotton 
stalks, Leucaena leucocephala and Chamaecytisus proliferus, and of their ethyleneglycol pulps. Bioresource technology, 98 (18): 3487-3490.

http://dx.doi.org/10.1016/j.biortech.2006.11.009

25. Kaldor, A., 1992: Kenaf, an alternative fiber for the pulp and paper industries in developing and developed countries. Tappi journal, pp. 141

26. Maugard, T.; Enaud, E.; Choisy, P.; Legoy, M. D., 2001: Identification of an indigo precursor from leaves of Isatis tinctoria (Woad). Phytochemistry, 58 (6): 897-904. http://dx.doi.org/10.1016/S0031-9422(01)00335-1

27. Reddy, N.; Yang, Y., 2009: Properties and potential applications of natural cellulose fibers from the bark of cotton stalks. Bioresource technology,100 (14): 3563-3569. http://dx.doi.org/10.1016/j.biortech.2009.02.047

28. Samp, J. C., 2008: A comprehensive mechanism for anthraquinone mass transfer in alkaline pulping. ProQuest, Georgia Institute Technology, p. 120.

29. Stoker, K. G.; Cooke, D. T.; Hill, D. J., 1998a. Influence of light on natural indigo production from woad (Isatis tinctoria). Plant Growth Regulation, 25 (3): 181-185. http://dx.doi.org/10.1023/A:1006042331385

30. Stoker, K. G.; Cooke, D. T.; Hill, D. J., 1998b. An improved method for the large-scale processing of woad (Isatis tinctoria) for possible commercial production of woad indigo. Journal of Agricultural Engineering Research, 71 (4): 315-320. http://dx.doi.org/10.1006/jaer.1998.0329

31. Tutus, A.; Eroglu, H., 2003: A practical solution to silica problem in straw pulping. APPITA, Australia J., 56 (2): 111-115.

32. Tutus, A.; Ezici, A. C.; Ates, S., 2010a: Chemical, morphological and anatomical properties and evaluation of cotton stalks (Gossypium hirsutum L.) in pulp industry. Scientific Research and Essays, 5 (12): 1553-1560.
33. Tutus, A.; Comlekcioglu, N.; Karaman, S.; Alma, M. H., 2010b: Chemical composition and fiber properties of Crambe orientalis and C. tataria. International Journal of Agriculture and Biology, 12 (2): 286-290.

34. Tutus, A.; Çiçekler, M.; Karataş, B., 2011: Pulp and Paper Production by Kraft-Sodium Borohydride method from Poppy Stems. II. International Non-Wood Forest Products Symposium, pp.183-190, Isparta/Turkey.

35. Tutus, A.; Cicekler, M.; Altas, A., 2014: Evaluation of Astragalus membranaceus in Pulp and Paper Production. III. International Non-Wood Forest Products Symposium, 323-331, Kahramanmaras/Turkey.

36. Tutus, A.; Kazaskeroğlu, Y.; Cicekler, M., 2015: Evaluation of Tea Wastes in Usage Pulp and Paper Production. BioResources, 10 (3): 5407-5416.

http://dx.doi.org/10.15376/biores.10.3.5407-5416

37. Wise, E. L.; Karl, H. L., 1962: Cellulose and hemicelluloses in pulp and paper science and technology. Vol. I. Pulp edited by C. Earl Libby. McGraw Hill-Book Co., New York.

38. Young, J. H., 1981: Fiber preparation and approach flow in Pulp and Paper. In: Casey, James P. (ed.), Chemistry and Chemical Technology. Interscience publishers, New York.

\section{Corresponding address:}

Prof. NAZAN COMLEKCIOGLU, Ph.D.

Biology Department

Faculty of Science and Letters, KSU

46060, Kahramanmaras, TURKEY

e-mail: noktem@ksu.edu.tr 